\title{
Optimization of Somatic Embryogenesis Induction of Cassava (Manihot esculenta Crantz)
}

\author{
Idha Susanti ${ }^{1, *}$, Suharsono ${ }^{1}$, Utut Widyastuti ${ }^{1}$, Ulfah Juniarti Siregar ${ }^{2}$ and Aris Tjahjoleksono ${ }^{1}$ \\ ${ }^{1}$ Department of Biology Faculty of Mathematics and Natural Sciences \\ Bogor Agricultural University Bogor, Indonesia \\ ${ }^{2}$ Department of Silviculture Faculty of Forestry \\ Bogor Agricultural University Bogor, Indonesia
}

\begin{abstract}
The somatic embryogenesis (SE) has an important role for genetic engineering of cassava (Manihot esculenta Crantz). However, the success of SE induction depends on plant growth regulators (PGR)s and treatment of enriched in the induction media. This experiment tried to induce cassava callus formation from in vitro immature leaf lobes, and to develop cassava somatic embryogenesis in several media enriched with tyrosine and copper sulphate (CuSO4) added into media contained with picloram as treatment. Different responses of explants source from three cultivars (Adira 4, Malang 6 and Sutera) in callus induction as well as friable callus formation were found in this experiment. The best medium to induce SE with cultivars: MS media supplemented $12 \mathrm{mg} / \mathrm{L}$ picloram $+0.5 \mathrm{mg} / \mathrm{L}$ CuSO4 was the best for "Adira 4" and half MS and half GD media supplemented $12 \mathrm{mg} / \mathrm{L}$ picloram $+100 \mathrm{mg} / \mathrm{L}$ tyrosine for "Malang 6". These treatments resulted in somatic embryo which could develop normally into plantlet.
\end{abstract}

Keywords: Manihot esculenta, embryogenic callus, picloram

*Corresponding author: Idha Susanti

Cibinong Science Center, Jl. Raya Bogor Km. 46, Cibinong 16911, Indonesia

Tel. +62-21-8754587, Fax. +62-21-87754588

E-mail. Idhasusanti1974@gmail.com

\section{Introduction}

Implementation of somatic embryogenesis (SE) has an important role in plant genetic engineering, one of which is in producing transgenic plant of cassava. A protocol that is precisely capable to produce friable embryogenic callus (FEC) with a high totipotent character is required to genetic transformation application. Common application of friable embryogenic callus is in transgenic plant collection by means particle bombardment, electroporation and Agrobacterium tumefaciens (Raemakers et al.2001; Liu et al. 2011).

The cassava somatic embryos induction research had been done indirectly which consist of three stages: callus induction, somatic embryogenesis induction, and regeneration stage (Zhang \& Gruissem 2004; Liu et al. 2011). The callus type that has good ability to produce somatic embryos and should be found on the first stage is friable embryonic callus (FEC). The second stage (somatic embryos induction stage) is the crucial stage because some cultivars tends to show the recalcitrant response (Liu et al. 2011). The regeneration on the third stage was purposed to induce germination and produce plantlets.

Auxin is the growth regulators (PGR)'s that could to induce somatic embryogenesis. Some types of auxin reported on cassava research are 2,4D, NAA, Dicamba, TDZ, IAA, and picloram. However, the most suitable auxin for somatic embryogenesis on cassava is picloram (Mongomake et al. 2015). The concentration of picloram application was varied, depending on the treatment design and plant genotype. Most of the application of picloram for the best result was $10-12 \mathrm{mg} / \mathrm{L}$ (Saelim et al. 2006; Diantina 2014).

The administration of Cupper $(\mathrm{Cu})$ was reported could to improve the percentage of cassava somatic embryos induction, which is supplemented around $2 \mu \mathrm{M}$ into the growth media (Zainuddin el al. 2012; Diantina 2014). To produce cassava somatic embryos, induction medium is enriched with amino 
acids, which are glutamine (Hartati et al. 2012), tyrosine (Taylor et al.; 1996; Sudarmonowati et al. 2009; Nyaboga et al. 2015) and glycine (Wongtiem et al. 2011).

Genetic engineering of cassava depends on cell stock support, which has good ability to regenerate into plant, in this case is somatic embryos. Previous studies of cassava indicates that the formation of somatic embryogenesis in cassava shows high dependency to its genotype, it is notable that some of the cassava cultivars are susceptible to somatic embryogenesis and regeneration (Raemakers et al. 2001; Hankoua et al. 2005). Therefore it becomes necessary to optimize the production of embryonic line for each local cassava cultivar.

This study aimed to optimize the somatic embryogenesis treatment medium using several different genotype sources to express a high frequency of callus and somatic embryos formation.

\section{Materials and Methods}

Callus Induction. The in vitro collection were cassava cultivar Sutera (cultivar from Bangka Island), cultivar Malang 6 and cultivar Adira 4 (cultivars from BALITKABI). Those cultivars had been cultured in vitro and were maintained on medium containing half MS (Murashige and Skoog 1962) basal salts and vitamins supplemented with $15 \mathrm{~g} / \mathrm{L}$ sucrose and $0.8 \%$ agar. The plant was incubated at a temperature of $24-25^{\circ} \mathrm{C}$ under 24 -hour-light provided by white fluorescent tubes at an intensity 8001000 lux.

In vitro explants used in callus induction experiment were immature leaf lobes size 3-10 $\mathrm{mm}$. Explants were excised and cultured on three combination media treatments: MS (Murashige \& Skoog 1962) basal salt and vitamin supplemented with $2 \%$ sucrose as control (C0), MS basal salt and vitamin supplemented with $4 \%$ sucrose, $12 \mathrm{mg} / \mathrm{L}$ picloram, and $2 \mu \mathrm{M} \mathrm{CuSO} 4$ (C1 medium); MS basal salt and MW vitamin (Morel \& Wetmore 1951), 3\% sucrose, $25 \mathrm{mg} / \mathrm{L}$ picloram, $25 \mathrm{mg} / \mathrm{L} \mathrm{NAA}$, and $100 \mathrm{mg} / \mathrm{L}$ casein hydrolyzed (C2 medium); and MS basal salt and vitamin supplemented with $4 \%$ sucrose, 10 $\mathrm{mg} / \mathrm{L}$ picloram, $0.01 \mathrm{M}$ glutamine, and $2 \mu \mathrm{M}$ $\mathrm{CuSO} 4$ (C3 medium). The entire medium was adjusted to $\mathrm{pH} 5.8$ prior to the addition of $8 \%$ agar, autoclaved at $120^{\circ} \mathrm{C}$, then cultured under dark condition at a temperature of $24-25^{\circ} \mathrm{C}$ for 6 weeks. Sub culture on the same medium was done every 3 weeks.

Somatic Embryogenesis Induction. Callus used in somatic embryogenesis induction experiment from previous stage was excised and cultured on three combination media treatment: MS basal salt and vitamin supplemented with $2 \%$ sucrose, $12 \mathrm{mg} / \mathrm{L}$ picloram, and $2 \mu \mathrm{M}$ CuSO4 (M medium); GD (Gresshoff \& Doy 1974) basal salt and vitamin, $20 \mathrm{~g} / \mathrm{L}$ sucrose, and $12 \mathrm{mg} / \mathrm{L}$ picloram ( $\mathrm{G}$ medium); 1/2 MS basal medium and vitamin, $1 / 2$ GD basal salt and vitamin, 20 $\mathrm{g} / \mathrm{L}$ sucrose, $12 \mathrm{mg} / \mathrm{L}$ picloram, and $100 \mathrm{mg} / \mathrm{L}$ tyrosine (GMT medium).

Mature embryos were transferred to the germination medium (MS basal salt and vitamin supplemented with $2 \%$ sucrose dan 0.4 $\mathrm{mg} / \mathrm{L}$ BAP) to induce bud. The sub cuture onto developmental medium (MS medium without plant growth regulators) were done for rooting stage and to develop it to individual plantlet.

The entire medium was adjusted to $\mathrm{pH} 5.8$ prior to the addition of $8 \%$ agar, autoclaved at $120^{\circ} \mathrm{C}$, then cultured under $16 / 8 \mathrm{~h}$ photopheriod condition at a temperature of 24$25^{\circ} \mathrm{C}$ for 10 weeks. Sub culture on the same medium treatments were done every 3 weeks. Embryonic structures were examined using a stereomicroscope.

\section{Results}

Callus Induction. All cassava cultivars successfully produced callus on all medium treatments in varies percentage (Table 1). Callus inductions were achieved within 11 days after treatment on media $\mathrm{C} 1$ and $\mathrm{C} 3$. Analysis of variance showed that the treatment significantly different between the factors tested. The average of callus induction time which was required for callus proliferation from explant was between 11-15 days.

Following analysis using analysis of variance shows significant differences between the cultivars and medium treatment factors tested. Malang 6 was the cultivar with the earliest callus induction time but Adira 4 had the highest frequency of callus induction. Adira 4 cultivar was more responsive and commonly has higher the callusing degree in some of callus induction medium treatmens. 
Table 1. Effect of media treatment on callus formation derived from immature leaf lobus of cassava cultivars

\begin{tabular}{cccc}
\hline Cultivar & Media Treatment & Induction Time (day) & Frequency (\%) Callus per disk \\
\hline Adira 4 & $\mathrm{C} 0$ & $>42 \pm 42 \mathrm{c}$ & $0 \pm 0$ \\
& $\mathrm{C} 1$ & $12 \pm 8.5 \mathrm{ab}$ & $71.88 \pm 0.5 \mathrm{bcd}$ \\
& $\mathrm{C} 2$ & $12.625 \pm 13.5 \mathrm{ab}$ & $81.25 \pm 0.35 \mathrm{abc}$ \\
& $\mathrm{C} 3$ & $12.375 \pm 12 \mathrm{ab}$ & $90.63 \pm 0.25 \mathrm{ab}$ \\
\hline Malang 6 & $\mathrm{C} 0$ & $>42 \pm 42 \mathrm{c}$ & $0 \pm 0$ \\
& $\mathrm{C} 1$ & $10.75 \pm 10.5 \mathrm{a}$ & $93.75 \pm 0.25 \mathrm{ab}$ \\
& $\mathrm{C} 2$ & $15.25 \pm 16 \mathrm{~b}$ & $100 \pm 1 \mathrm{a}$ \\
& $\mathrm{C} 3$ & $10.75 \pm 11.5 \mathrm{a}$ & $34.38 \pm 0.25 \mathrm{e}$ \\
\hline \multirow{2}{*}{ Sutera } & $\mathrm{C} 0$ & $>42 \pm 42 \mathrm{c}$ & $0 \pm 0$ \\
& $\mathrm{C} 1$ & $12.75 \pm 15.5 \mathrm{ab}$ & $62.50 \pm 0.35 \mathrm{~cd}$ \\
& $\mathrm{C} 2$ & $13.75 \pm 13 \mathrm{ab}$ & $56.25 \pm 0.35 \mathrm{~d}$ \\
& $\mathrm{C} 3$ & $14.75 \pm 10 \mathrm{ab}$ & $18.75 \pm 0.125 \mathrm{ef}$ \\
\hline
\end{tabular}

Note: Means \pm standard error within a column followed by the different letters are significantly different at $\mathrm{P} \leq 0.05$ by ANOVA

Different responses of cultivar to treatments indicate the plant cell capability to produce callus is vary. Observations of callus cells formation were conducted to ascertain the callus formation classified to FEC or not. The FEC is indicated by the formation of unorganized friable, shiny and yellowish-white callus. Observation on callus performances show that $\mathrm{C} 3$ medium treatment test could not induced all cultivars to FEC. Callus formation performed by explants on $\mathrm{C} 3$ medium produced compact callus with yellowish-green or yellowish-brown color, indicated non embryonic callus. Meanwhile, explants on medium treatment of $\mathrm{C} 1$ and $\mathrm{C} 2$ were responsive to produce callus with FEC feature. Callus obtained from $\mathrm{C} 1$ and $\mathrm{C} 2$ medium have friable callus structure for majority of cultivar.

Variation of induction time, percentage of callus induction, and callus type indicated the differences between cultivar's responses in somatic embryos formation, as well as their response to the type and concentration of auxin.

Somatic Embryogenesis Induction. Three cultivars from previous stage (callus induction stage) were evaluated to examine their potency to produce somatic embryos and to regenerate it into a complete plant. The data of somatic embryogenesis induction (Table 2) shows only
2 out of 36 combination treatments were successful to induced somatic embryogenesis. The trends of somatic embryogenesis results of this research are differed and show specific response between genotype and medium treatment. Adira 4 responsed specifically to $\mathrm{M}$ medium and Malang 6 produced somatic embryos only on GMT medium. Callus proliferation to somatic embryos was not found on G medium and cultivar Sutera.

Based on three compared mediums, the earliest period for obtaining initial somatic embryos was observed in Adira 4 from callus of leaf lobes explant, i.e. 8 weeks incubation. The total frequency of somatic embryos of Adira 4 on $\mathrm{M}$ medium was $37.5 \%$, higher than other treatments in this experiment. Within this experiment $G$ medium could not induce somatic embryos from all of cultivars. The $G$ medium is reported by some publications can initiate and induce proliferation of FEC from high-quality embryogenic tissue (Bull et al. 2009; Nyaboga et al. 2015). 
Table 2. Effect of media treatment combination on somatic embryogenesis derived from immature leaf lobus of cassava cultivars

\begin{tabular}{|c|c|c|c|c|c|}
\hline \multirow{2}{*}{ Cultivar } & \multicolumn{2}{|c|}{ Media Treatment Combination } & \multirow{2}{*}{$\begin{array}{l}\text { Total Frequency } \\
(\%)\end{array}$} & \multirow{2}{*}{$\begin{array}{c}\text { Frequency (\%) SE } \\
\text { per Disk }\end{array}$} & \multirow{2}{*}{$\begin{array}{l}\text { Number of Embryo } \\
\text { per Clump }\end{array}$} \\
\hline & Callus Stage & SE Stage & & & \\
\hline \multirow{9}{*}{ Adira 4} & \multirow{3}{*}{$\mathrm{C} 1$} & G & 0 & $0 \pm 0$ & $0 \pm 0$ \\
\hline & & M & 0 & $0 \pm 0$ & $0 \pm 0$ \\
\hline & & GMT & 0 & $0 \pm 0$ & $0 \pm 0$ \\
\hline & \multirow{3}{*}{$\mathrm{C} 2$} & G & 0 & $0 \pm 0$ & $0 \pm 0$ \\
\hline & & M & 37.5 & $67 \pm 41.5 \mathrm{a}$ & $13.75 \pm 15.5 \mathrm{a}$ \\
\hline & & GMT & 0 & $0 \pm 0$ & $0 \pm 0$ \\
\hline & \multirow{3}{*}{$\mathrm{C} 3$} & G & 0 & $0 \pm 0$ & $0 \pm 0$ \\
\hline & & M & 0 & $0 \pm 0$ & $0 \pm 0$ \\
\hline & & GMT & 0 & $0 \pm 0$ & $0 \pm 0$ \\
\hline \multirow{9}{*}{ Malang 6} & \multirow{3}{*}{$\mathrm{C} 1$} & $\mathrm{G}$ & 0 & $0 \pm 0$ & $0 \pm 0$ \\
\hline & & M & 0 & $0 \pm 0$ & $0 \pm 0$ \\
\hline & & GMT & 25 & $41.5 \pm 25 b$ & $6.25 \pm 3 b$ \\
\hline & \multirow{3}{*}{$\mathrm{C} 2$} & $\mathrm{G}$ & 0 & $0 \pm 0$ & $0 \pm 0$ \\
\hline & & M & 0 & $0 \pm 0$ & $0 \pm 0$ \\
\hline & & GMT & 0 & $0 \pm 0$ & $0 \pm 0$ \\
\hline & \multirow{3}{*}{$\mathrm{C} 3$} & G & 0 & $0 \pm 0$ & $0 \pm 0$ \\
\hline & & M & 0 & $0 \pm 0$ & $0 \pm 0$ \\
\hline & & GMT & 0 & $0 \pm 0$ & $0 \pm 0$ \\
\hline \multirow{9}{*}{ Sutera } & \multirow{3}{*}{$\mathrm{C} 1$} & $\mathrm{G}$ & 0 & $0 \pm 0$ & $0 \pm 0$ \\
\hline & & M & 0 & $0 \pm 0$ & $0 \pm 0$ \\
\hline & & GMT & 0 & $0 \pm 0$ & $0 \pm 0$ \\
\hline & \multirow{3}{*}{$\mathrm{C} 2$} & G & 0 & $0 \pm 0$ & $0 \pm 0$ \\
\hline & & $\mathrm{M}$ & 0 & $0 \pm 0$ & $0 \pm 0$ \\
\hline & & GMT & 0 & $0 \pm 0$ & $0 \pm 0$ \\
\hline & \multirow{3}{*}{$\mathrm{C} 3$} & $\mathrm{G}$ & 0 & $0 \pm 0$ & $0 \pm 0$ \\
\hline & & M & 0 & $0 \pm 0$ & $0 \pm 0$ \\
\hline & & GMT & 0 & $0 \pm 0$ & $0 \pm 0$ \\
\hline
\end{tabular}

Note: Means \pm standard error within a column followed by the different letters are significantly different at $\mathrm{P} \leq 0.05$ by ANOVA

Somatic embryogenesis phases of Adira 4 and Malang 6 were similar. The phases consist of globular, heart, torpedo, and cotyledon phases (Figure 1). After 10 weeks incubation with treatment medium, the phases of induction were vary and it shows that Adira 4 produced more SE and had higher developmental stages (torpedo-shaped embryos) than Malang 6 (Table 2).

The differences in terms of amount of SE which were produced and the type of developmental stages (such as globular or torpedo embryos) may be explained by the genotype-medium combination. The ability of cassava genotypes to produce somatic embryos is influenced by the callus type as well as the type and concentration of auxin, $\mathrm{Cu}$, and amino acid concentration.

In addition, longer culture time shows the presence of abnormal embryos during observation (Figure 2B and 2C). After it was transferred to the development medium, a number of these embryos did not exhibit normal development into plants. 

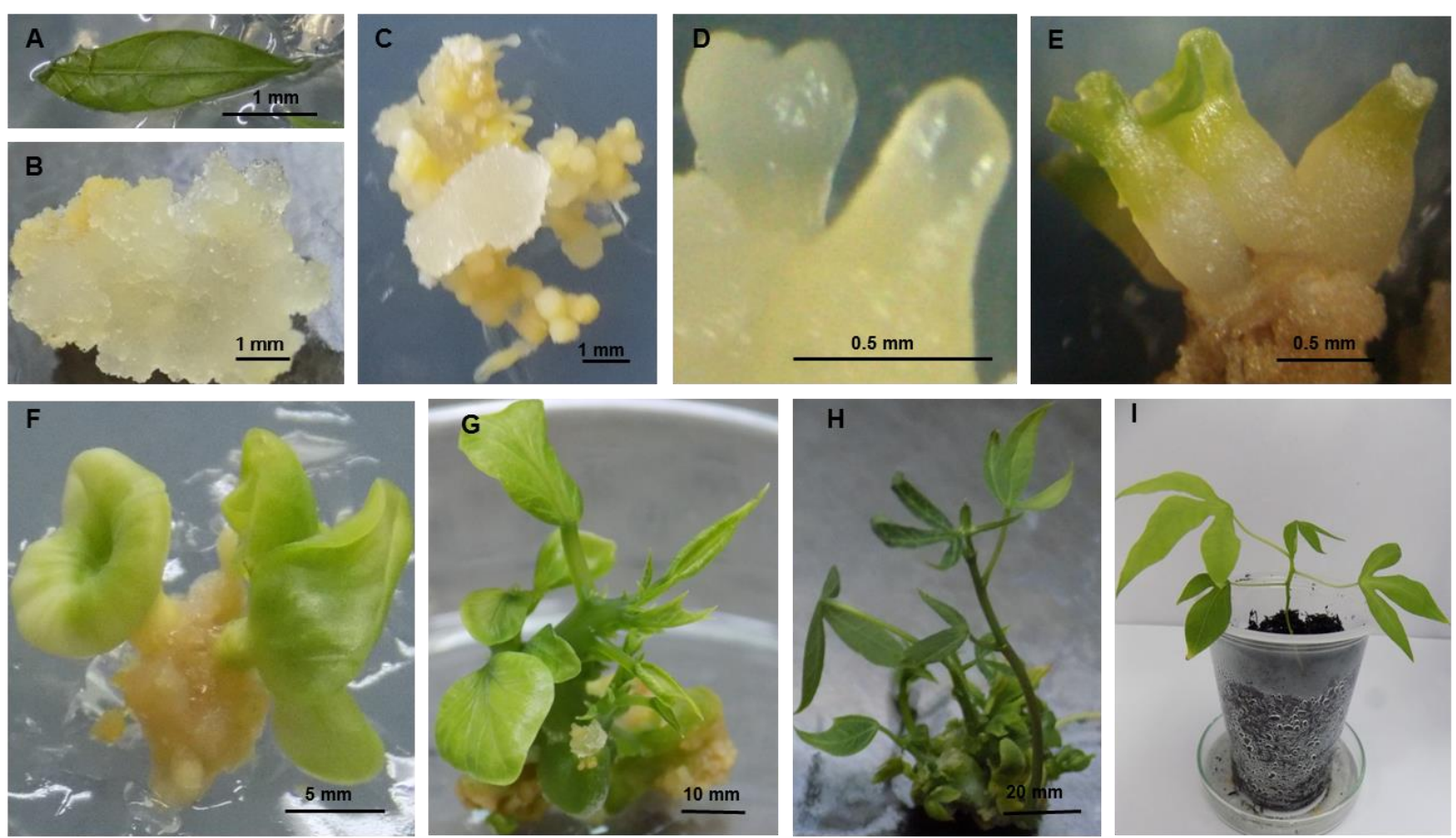

Figure 1. Morphological stages of somatic embryos in cassava cultivar Adira 4. Immature leaf lobe explant (A), induced compact non-embryogenic callus (B), somatic embryos masses (C), globular and heart structures (D), green cotyledonary stage (E), derived from green cotyledons developed clusters of shoot buds (F-G), regenerated plants $(\mathrm{H})$, and acclimatized plantlet(I)

\section{Discussion}

Addition of a strong auxin to the culture medium is efficient to induce in vitro somatic embryogenesis. In this research, picloram induced SE of Adira 4 and Malang 6. Picloram is recommended auxin to produce embryonic callus of cassava and could induce SE of local cassava cultivar 433 (Diantina 2014); African cultivars TME13, 127, 8, 1, TMS I 91/02327 60444 (Hankoua et al. 2006); model cultivar 60444 (Zhang \& Gruissem 2004; Bull et al. 2009; Zainuddin et al. 2012); and Brazilian cultivar Cigana Preta (Vidal et al. 2014). Picloram treatment could also induce primary SE in a higher frecuency than others auxin to cultivars Sekelen, Ngan Mbada, Lokal red and Local ama from Cameroon (Mongomake et al. 2015).

There was variable result of auxin application to cultivar 60444, it was reported $2,4 \mathrm{D}$ induced higher SE frequency than picloram (Marigi et al. 2016). Similar report confirmed by Anuradha et al. (2015) who assessed cultivars from Indian (H-226), they found 2,4 D tends to increase production of soft callus, which is proficient in developing somatic embryos.

Visualization of cell culture with stereomicroscopy in this study revealed the formation of somatic embryos phases on the same piece of callus tissue (asynchronous). Other findings also validate the characterization of asynchronous SE of cassava (Vidal et al. 2014; Mongomake et al. 2015).

In this study, cultivar Sutera did not demonstrate its ability to produce somatic embryos, therefore optimized treatment for Sutera cultivar becomes imperative. Additional combination of different plant growth regulator might be valuable to allow potential improvement on SE induction. Some cultivars with lack ability of somatic embryogenesis could be classified as recalcitrant genotype. Cassava with recalcitrant feature is characterized by zero or low amenable response to plant growth regulator given on somatic embryogenesis stage. 


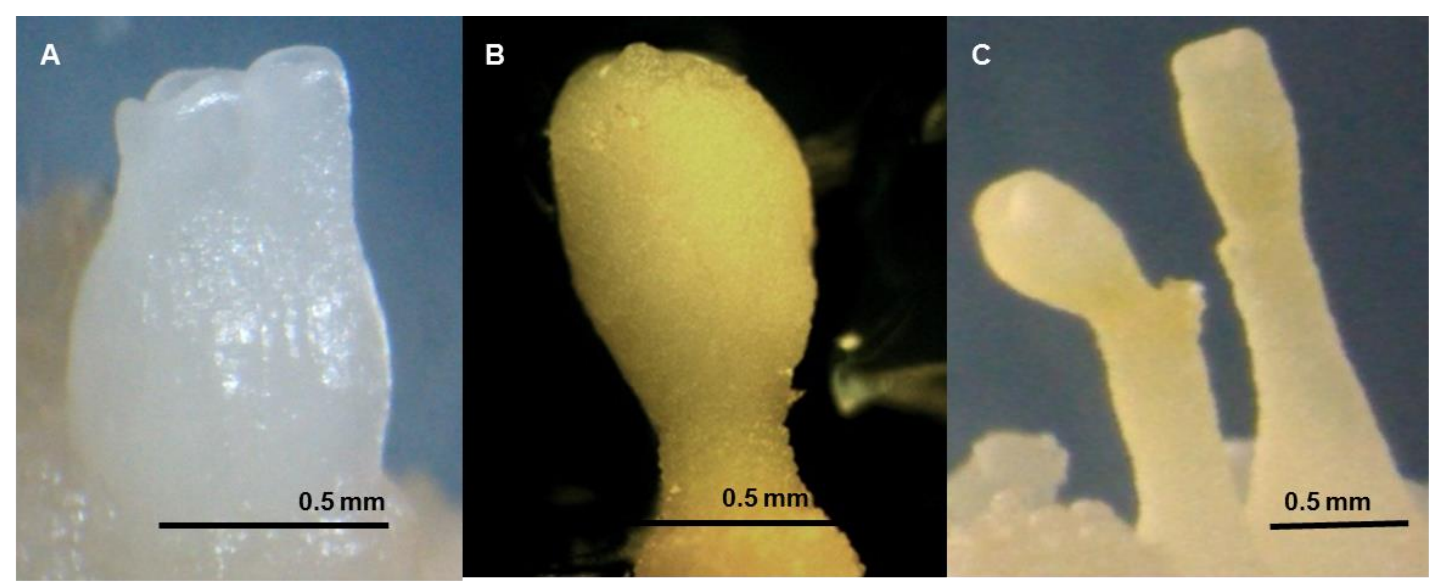

Fig. 2 Cotyledone stage of cassava with normal morphology (A) and abnormal morphology (B, C)

The recalcitrant feature is found in some research of cassava. The frequency and productivity of somatic embryogenesis depend on genotype to be performed (Hankoua et al. 2005). Some of cassava cultivars are failed to synchronize their genotype-phytohormone interaction to form somatic embryogenesis, regeneration and / or transformation (Mongomake et al. 2015). A study conducted in 1997 by Raemakers and colleagues states that even if recalcitrant genotypes are successful in developing proembryonic structure or globular stage embryos, they found that those genotypes were unsuccesful in developing torpedo-shaped or mature embryos.

\section{Conclusion}

The combination of cultivar and medium treatment on both stages (callus and SE induction) influenced the response of cell to embryogenesis. The callus of immature leaf lobes explant of Adira 4 on $\mathrm{M}$ medium (supplemented with $12 \mathrm{mg} / \mathrm{L}$ picloram, and 2 $\mu \mathrm{M}$ CuSO4) gave the best response to $\mathrm{SE}$ induction and successfully developed from callus to plant.

\section{References}

Anuradha, T., Kumar, K. K., \& Balasubramanian, P. (2015). Cyclic somatic embryogenesis of elite Indian cassava variety $\mathrm{H}-226$. Indian $J$. of Biotechnology 14, 559-565.
Bull, S. E., Owiti, J. A., Niklaus, M., Beeching, J. R., Gruissem, W., \& Vanderschuren, H. (2009). Agrobacterium-mediated transformation of friable embryogenic calli and regeneration of transgenic cassava. Nature protocols 4 (12),1845-1854. doi:10.1038/nprot.2009.208.

Diantina, S. (2014). Konservasi tunas in vitro dan populasi sel embriogenik ubi kayu secara pertumbuhan minimal dan kriopreservasi (Master thesis, Bogor: Bogor Agricultural University).

Gresshoff, P. M., \& Doy, C. H. (1974). Description of a haploid cell line from Vitis visiflora and importance of meiotic development of anthers for haploid culture of this and other genera. $Z$. Pfl anzenphysiologie 50, 132-141.

Hankoua, B. B., Ng, S. Y. C., Fawole, I., PuontiKaerlas, J., Pillay, M., \& Dixon, A. G. O. (2005). Regeneration of a wide range of African cassava genotypes via shoot organogenesis from cotyledons of maturing somatic embryos and conformity of the field-established regenerants. Plant Cell, Tissue and Organ Culture 82, 221231. doi:10.1007/s11240-005-0514-5.

Hartati, N.S., Sudarmonowati, E., Rahman, N., Fitriani, H., Supatmi., Kurniawati, S., \& Fathoni, A. (2012). Laporan Teknik Pusat Penelitian Biologi LIPI Tahun Anggaran 2012. (Cibinong: Pusat Penelitian Biologi LIPI).

Liu J, Zheng Q, Ma Q, Gadidasu KK, Zhang P. 2011. Cassava Genetic Transformation and its Application in Breeding. J. of Integrative Plant Biol. 53 (7), 552-569. doi: 10.1111/j.17447909.2011.01048.x.

Marigi, E.N., Masanga, J.O., Munga, T.L., Karanja, L.S., Ngugi, M.P., Thagana, W.M., Kirubi, D., Mwangi, M., Githunguri, C.M., Muiru, W.M., Miano, D.W., \& Alakonya, A.E. (2016). Protocol for farmer-preferred cassava cultivars in Kenya. African Crop Sci. J. 24, 35-44. doi: 10.4314/acsj.v24i1.4S 
Mongomake, K., Doungous, O., Khatabi, B., \& Fondong, V. N. (2015). Somatic embryogenesis and plant regeneration of cassava (Manihot esculenta Crantz) landraces from Cameroon. SpringerPlus 4, 477. doi 10.1186/s40064-015-1272-4.

Morel, G., \& Wetmore, R. M. (1951). Fern callus tissue culture. Am. J. Bot. 38, 141-143

Murashige, T., \& Skoog, F. (1962). A revised medium for rapid growth bioassays with tobacco tissue culture. Physiol. Plant. 15, 473497.

Nyaboga, E.N., Njiru, J.M, \& Tripathi, L. (2015). Factors influencing somatic embryogenesis, regeneration, and Agrobacterium-mediated transformation of cassava (Manihot esculenta Crantz) cultivar TME14. Frontiersin Plant Science 6:1-13 doi: 10.3389/fpls.2015.00411.

Raemakers, K. J. J. M., Sofiari, E., Jacobsen, E., \& Vissser, R. G. F. (1997). Regeneration and transformation of cassava. Euphytica. 96, 153161.

Raemakers, K., Schreuder, M., Pereira, I., Munyikwa, T., Jacobsen, E., \& Visser, R. (2001). Progress made in FEC transformation of cassava. Euphytica 120,15-24.

Saelim, L., Salak, Phansiri, Netrphan, S., Suksangpanomrung, M., \& Narangajavana J. (2006). Optimization of In vitro Cyclic Somatic Embryogenesis and Regeneration of the Asian Cultivars of Cassava (Manihot esculenta Crantz) for Genetic Manipulation System. Global J. of Biotechnol and Biochem. 1 (1), 0715.
Sudarmonowati, E., Fitriani, H., Supatmi, \& Ardiyanti, N. (2009). Factors affecting friable embryonic callus in several plant species. J. of Biotech. Research in Tropical Region 2(2), 1-5.

Taylor NJ, Edwards M, Kiernan RJ, Davey CDM, Blakesay D, Henshaw GG. (1996). Development of friable embrygenic callus and embryogenic suspension culture systems in cassava (Manihot esculenta Crantz). Nature Biotech. 14:726-730.

Vidal, Á. M., Costa, M. A. P. D. C., Souza, A. D. S., Almeida, W. A. B. D., \& Souza, F. V. D. (2014). In vitro regeneration and morphogenesis of somatic embryos of cassava. Revista Ciência Agronômica 45, 558-565. doi:10.1590/S180666902014000300017.

Wongtiem, P., Courtois, D., Florin, B., Juchaux, M., Peltier. D., Broun, P., \& Ducos, J. P. (2011). Effect of cytokinins on secondary somatic embryogenesis of selected clone Rayong 9 of Manihot esculenta Crantz for ethanol production. African J of Biotech. 10(9), 1600-1608. doi: 10.5897/AJB10.1820.

Zainuddin, I. M., Schlegel, K., Gruissem, W., \& Vanderschuren, H. (2012). Robust transformation procedure for the production of transgenic farmer-preferred cassava landraces. Plant Methods 8, 24. doi: 10.1186/1746-48118-24.

Zhang, P., \& Gruissem, W. (2004). Production of transgenic cassava (Manihot esculenta Crantz). Transgenic Crops of the World - Essential Protocols. Chapter 23, 301-319 (Netherlands: Kluwer Academic Publishers). 